\title{
Wpływ superplastyfikatora na hydrofilowość zaczynów cementowych
}

\begin{abstract}
Zaprojektowanie receptury zaczynu o parametrach reologicznych umożliwiających uzyskanie wymaganych warunków przepływu pozwala na otrzymanie odpowiedniego współczynnika wyparcia płuczki, na usunięcie pozostałości osadu płuczkowego oraz wypełnienie skawernowanej przez świder powierzchni górotworu. Uzyskanie wymaganych parametrów reologicznych, a tym samym optymalnej przetłaczalności zaczynu cementowego w przestrzeni pierścieniowej otworu wiertniczego, jest możliwe wskutek modyfikacji receptury zaczynu poprzez zastosowanie dodatków dyspergujących, tj. plastyfikatorów bądź superplastyfikatorów. Środki te, działając dyspergująco, powodują również obniżenie napięcia powierzchniowego zaczynu. Ponadto środki upłynniające przyczyniają się do zmiany hydrofilowości zaczynu, co jest istotne z punktu widzenia odpowiedniego nawilżenia powierzchni, do których przylega wiążący zaczyn cementowy. Wpływa to na wzrost przyczepności płaszcza cementowego do powierzchni styku. Dotychczas badania hydrofilowości wykonywane były jedynie dla różnego rodzaju środków polimerowych lub podobnych substancji, natomiast dla dyspersyjnego układu zaczynu cementowego modyfikowanego za pomocą superplastyfikatorów nie prowadzono tego rodzaju badań. W niniejszej publikacji podjęte zostały próby określenia hydrofilowości zaczynów cementowych z dodatkiem środków dyspergujących. Wykonano badania receptur kontrolnych (niepoddanych modyfikacji) oraz zaczynów zawierających określone ilości superplastyfikatora. Wykazano, że stosowane polimerowe dodatki superplastyfikatorów nie tylko wpływają na obniżenie parametrów reologicznych zaczynów cementowych, ale również powodują obniżenie napięcia powierzchniowego i zwiększenie hydrofilowości zaczynu. Uzyskane wyniki badań pozwalają lepiej zrozumieć mechanizmy zachodzące w dyspersyjnym układzie zaczynu cementowego, który poddano modyfikacji za pomocą środka upłynniającego, co może się przyczynić do poprawy szczelności na kontakcie płaszcza cementowego z powierzchniami styku.
\end{abstract}

Słowa kluczowe: zaczyn cementowy, superplastyfikator, środek upłynniający, hydrofilowość, poprawa uszczelnienia.

\section{The influence of a superplasticizer on the hydrophilicity of cement slurries}

The design of cement slurry with rheological parameters enabling obtaining the required flow regimes, allows to achieve the appropriate mud displacement coefficient, removing the residue of the mud cake and filling the surface of the wellbore rocks caverned by the drill. Obtaining the required rheological parameters, and thus optimal circulation of cement slurry in the annular space of the borehole is possible due to the modification of the cement slurry recipe by the use of dispersing additives, i.e. plasticizers or superplasticizers. These additives acting dispersingly also reduce the surface tension of the cement slurry. Furthermore, plasticizers contribute to change in the hydrophilicity of the slurry, which is important for the proper hydration of the surfaces to which the binding cement slurry adheres. This results in increased adhesion of the cement sheath to the contact surface. So far, hydrophilicity studies have been conducted only for various types of polymeric agents or similar substances, whereas for dispersive systems of cement slurry modified with superplasticizers they were not. This article presents attempts to determine the hydrophobicity of cement slurries with the addition of dispersing agents. Base cement slurries (unmodified) were tested as well as slurries containing a specified amount of superplasticizer. Studies have shown that the polymeric superplasticizer additives used, not only reduced the rheological parameters of cement slurries, but also reduced the surface tension and increased the hydrophilicity of the slurries. The obtained test results allow to better understand the mechanisms occurring in the dispersive system of cement slurry, which has been modified by a dispersing agent, which may contribute to the improvement of the sealing of the contact between the cement sheath and the contact surfaces.

Key words: cement slurry, superplasticizer, dispersant, hydrophilicity, sealing improvement. 


\section{Wprowadzenie}

Od czasu, kiedy zaczyny cementowe stosowane do uszczelniania otworów wiertniczych zawierały jedynie cement i wodę oraz niekiedy dodatek soli kamiennej bądź cukru w celu regulacji czasu wiązania, do dnia dzisiejszego nastąpiło wiele zmian. Obecne zaczyny cementowe przeznaczone do uszczelniania kolumn rur okładzinowych w otworze wiertniczym zawierają w swoim składzie szereg różnych dodatków i domieszek. W związku z tym współczesny zaczyn cementowy to bardzo złożony materiał o innych niż dawniej, zasadniczo zmienionych i znacznie poprawionych właściwościach. Głównym kierunkiem zmian parametrów zaczynów jest dążenie do ciągłej poprawy efektywności uszczelnienia kolumn rur okładzinowych. Zaczyny cementowe stosowane w przemyśle naftowym przeżywały podobny - jeśli nie bliźniaczy - postęp technologiczny jak beton cementowy w przemyśle budowlanym. Również kamienie milowe na drodze ewolucji wiertniczych zaczynów cementowych oscylują w podobnych okresach jak ważne daty na drodze postępu technologicznego związanego z rozwojem betonu $[5,10,11,14,18]$ (rysunek 1).

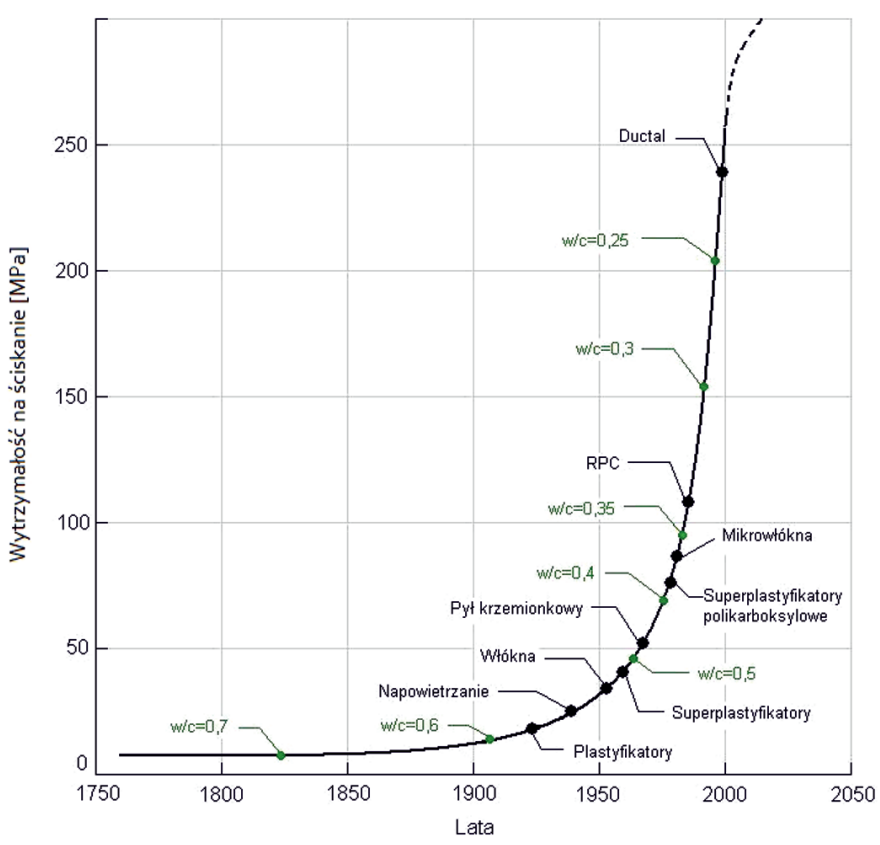

Rys. 1. Krzywa rozwoju betonu według L. Czarneckiego [5]

Stosowanie nowego rodzaju dodatków i domieszek do zaczynów cementowych wymusza na naukowcach przystosowywanie obecnych lub wprowadzanie coraz to nowszych metod badawczych. Takie działania umożliwiają w znacznie większym zakresie śledzenie zachodzących w zaczynie przemian fizykochemicznych, a tym samym dalszy rozwój technologii cieczy wiertniczych. W związku z powyższym w niniejszym artykule autorzy przedstawili nowy rodzaj badań wykonanych na zaczynach cementowych, czyli pomiar kąta zwilża- nia. Badania tego rodzaju są powszechnie prowadzone w chemii związków polimerowych i umożliwiają określenie właściwości hydrofilowych bądź hydrofobowych danej cieczy bądź powierzchni, na której ciecz się znajduje. Jednakże w przypadku zaczynów stosowanych w wiertnictwie takie badania stanowią swego rodzaju innowację $[4,12,19]$.

Środki chemiczne wykorzystywane do regulacji parametrów technologicznych zaczynów wiertniczych powodują w ich strukturze szereg różnego rodzaju zmian. Jak wiadomo, zaczyn cementowy jest cieczą pseudoplastyczną, czyli posiada cechy zarówno cieczy, jak i ciała stałego. Cechy te zmieniaja się w trakcie hydratacji ziaren cementu, do którego to procesu niezbędna jest obecność wody. W związku z tym, że zaczyn cementowy jest układem dyspersyjnym ciała stałego i cieczy, wykazuje on pewnego rodzaju powinowactwo do obu tych materiałów $[6,15]$. Badania hydrofilowości mogą się przyczynić do polepszenia zwilżania przez zaczyn powierzchni styku, co sprzyjać będzie poprawie wiązania zaczynu z powierzchniami styku, a tym samym efektywności uszczelniania kolumn rur okładzinowych.

Badania kąta zwilżania umożliwiają określenie hydrofilowości bądź hydrofobowości powierzchni lub cieczy. Cecha ta jest oparta na wzajemnym oddziaływaniu napięcia powierzchniowego cieczy i podłoża oraz energii powierzchniowej między tymi fazami. Powyższa energia, występująca na styku powierzchni cieczy i ciała stałego, jest miarą przyciągania cząsteczek cieczy do podłoża i określa się ją poprzez pomiar kąta zwilżania $\theta_{\mathrm{c}}$. Jest to kąt zawarty pomiędzy styczną powierzchni cieczy a powierzchnią ciała stałego (rysunek 2). Podczas pełnego zwilżania energia swobodna powierzchni posiada wartość równą lub większą niż napięcie powierzchniowe cieczy. Taki stan rzeczy występuje w przypadku stosowania cieczy hydrofilowych (małe wartości kąta zwilżania) (rysunek 2a). Natomiast w przypadku cieczy o właściwościach hydrofobowych kąt zwilżania jest stosunkowo duży, ponieważ ciecz o dużym napięciu powierzchniowym znajduje się na podłożu o niskiej energii powierzchniowej $[8,9,13]$ (rysunek $2 b$ ). Urządzenie zwane goniometrem pozwala zaobserwować punkt styczności na kontakcie faz przy dużym powiększeniu. Badanie kąta zwilżania umożliwia wstępne określenie

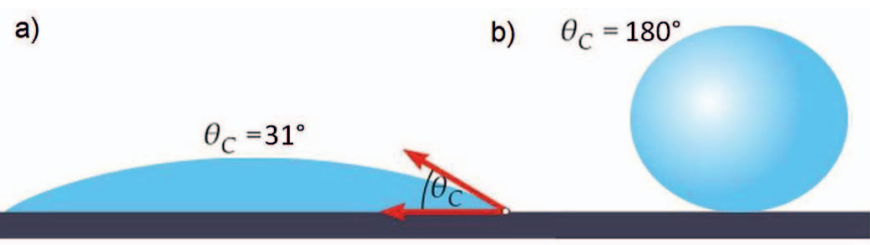

Rys. 2. Kąt zwilżania powierzchni: a) hydrofilowa; b) hydrofobowa 
wpływu stosowanych dodatków dyspergujących na hydrofilowość zaczynu cementowego [1-3, 7, 16].

Mówiąc o dodatkach dyspergujących, autorzy mają na myśli dodatki uplastyczniające bądź upłynniające strukturę zaczynów cementowych (plastyfikatory, superplastyfikatory). Obecnie dodatki tego rodzaju są najbardziej rozpowszechnionymi modyfikatorami. Zastosowanie dodatku plastyfikatora pozwala na obniżenie ilości wody zarobowej do $15 \%$ przy zachowaniu tej samej konsystencji zaczynu. Drugi rodzaj środka dyspergującego to superplastyfikator, umożliwiający obniżenie ilości wody zarobowej o ponad $15 \%$, a niekiedy nawet do $40 \%$. Najczęściej stosowane są dodatki dyspergujące na bazie lignosulfonianów, polimerów bądź tenzydów. Z punktu widzenia stosowalności w zaczynach cementowych najistotniejszą różnicą w powyższych środkach jest zasada działania. W przypadku lignosulfonianów i tenzydów właściwości dyspergujące oparte są na mechanizmie hydrofilowym (rysunek 3c), nato- miast w polimerach mamy do czynienia $\mathrm{z}$ mechanizmem sterycznym (rysunek 3d). Jednakże nie należy zapominać o podstawowym mechanizmie działania dodatków upłynniających, czyli elektrostatycznym (rysunek 3a) oraz smarnym (rysunek 3b) $[10,17,18,20]$.

Stosowanie dodatków dyspergujących w zaczynach cementowych jest niezwykle ważne nie tylko w aspekcie obniżenia ilości wody w zaczynie, ale również ze względu na uzyskanie turbulentnego przepływu przy niższych wydajnościach pomp podczas tłoczenia zaczynu na znaczne głębokości w otworze. Takie działanie omawianych dodatków przekłada się na dokładniejsze usunięcie płuczki z wypełnianej przestrzeni pierścieniowej przy jednocześnie obniżonym ryzyku rozszczelinowania złoża. Aby uzyskać taki przepływ (liczba Re > 3000), należy odpowiednio dobrać parametry reologiczne zaczynu cementowego, co możliwe jest właśnie dzięki stosowaniu dodatków upłynniających [17, 18].
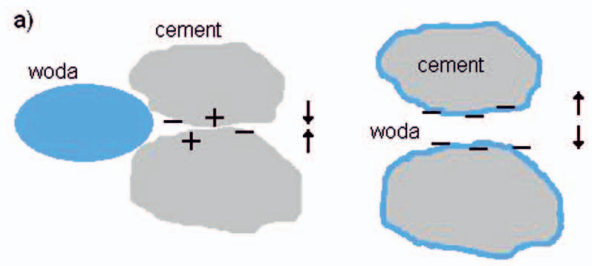

b)

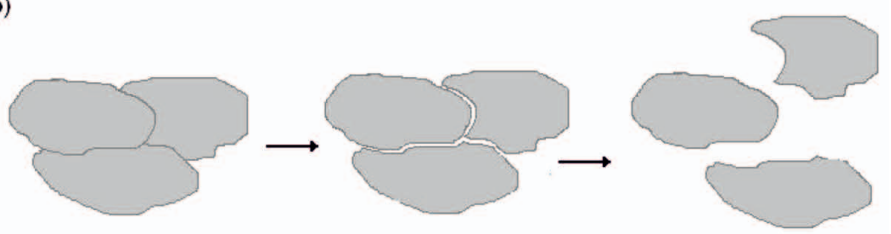

d)

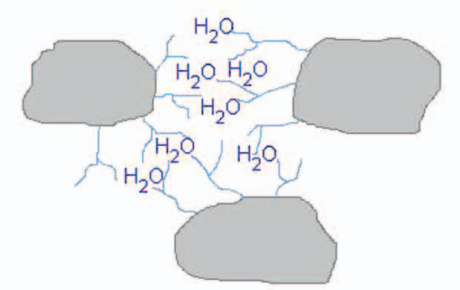

Rys. 3. Mechanizmy działania superplastyfikatorów (na podstawie [10] i [17])

\section{Część doświadczalna - materiały do badań}

W badaniach wykorzystano cement portlandzki CEM I klasy $32,5 \mathrm{R}$ o powierzchni właściwej $330 \mathrm{~m}^{2} / \mathrm{kg}$ według Blaine’a. Do sporządzenia zaczynu cementowego użyto wody wodociągowej. Jako związki dyspergujące zastosowano superpla- styfikatory SPA oraz SPB o składzie zakodowanym przez producenta. Są to środki o zawartości ponad $80 \%$ soli sodowej polikondensatów formaldehydowych kwasów naftalenosulfonowych.

\section{Metodyka badań}

Zaprezentowany w niniejszej publikacji cykl badawczy, którego celem było określenie wpływu dodatku superplastyfikatora na hydrofilowość zaczynów cementowych, wykonany został na podstawie normy PN-EN 10426-2 oraz API SPEC 10. Podczas realizacji prac badawczych dokonano pomiarów kąta zwilżania zaczynów z dodatkiem superplastyfikatorów. Dla potwierdzenia działania dodatków dyspergujących testy zostały poprzedzone badaniem parametrów re- ologicznych. Sporządzono dwa zaczyny kontrolne (do celów porównawczych): pierwszy - o „normowym” współczynniku wodno-cementowym wynoszącym $0,46^{1}$, drugi - mocno upłynniony wskutek użycia większej ilości wody, posiadający

\footnotetext{
${ }^{1}$ Stosunek wodno-cementowy to iloraz ilości wody do cementu w zaczynie cementowym; w/c $=0,46$ jest współczynnikiem ,normowym” zgodnie z normą PN-EN 10426.
} 
współczynnik w/c $=0,6$. Następnie przeprowadzono badania dla receptur o współczynniku w/c = 0,46 z dodatkiem 0,25\%, $0,50 \%$ i $1,0 \%$ superplastyfikatora SPA oraz tych samych ilości środka SPB. Udział superplastyfikatora wyrażono masowo w stosunku do ilości cementu. W celu oceny właściwości dyspergujących superplastyfikatora SPA i SPB przeprowadzono badania parametrów reologicznych przy użyciu wiskozymetru obrotowego. Wyznaczono krzywe płynięcia zaczynów uszczelniających w układzie współrzędnych: naprężenia ścinające $(\tau)$ - szybkość ścinania $(\gamma)$. Parametry reologiczne wyznaczono, opierając się na modelu reologicznym Cassona oraz Herschela-Bulkleya.

Drugie badanie wykonane na potrzeby niniejszej analizy to pomiar kąta zwilżania. Badanie prowadzono na stanowisku złożonym z aparatu (fotografia 1) firmy OCA 15EC DataPhysics z kamerą do wykonywania zdjęć kropli posadowionej na warstwę wierzchnią materiału wzorcowego (Sessile Drop-Method) oraz z programu SCA 20, służącego do analizy rejestrowanego obrazu kropli. Podczas badań kroplę zaczynu cementowego nanoszono za pomocą mikropipety, a następnie wykonywano pomiary kąta zwilżania. Objętość kropli pomiarowej wyniosła $5 \mu$, liczba nanoszonych kropli wynosiła 6 . Pomiar odbywał się w temperaturze $298 \mathrm{~K}\left(25^{\circ} \mathrm{C}\right)$ na płytce szklanej, którą przyjęto jako powierzchnię wzorcową.

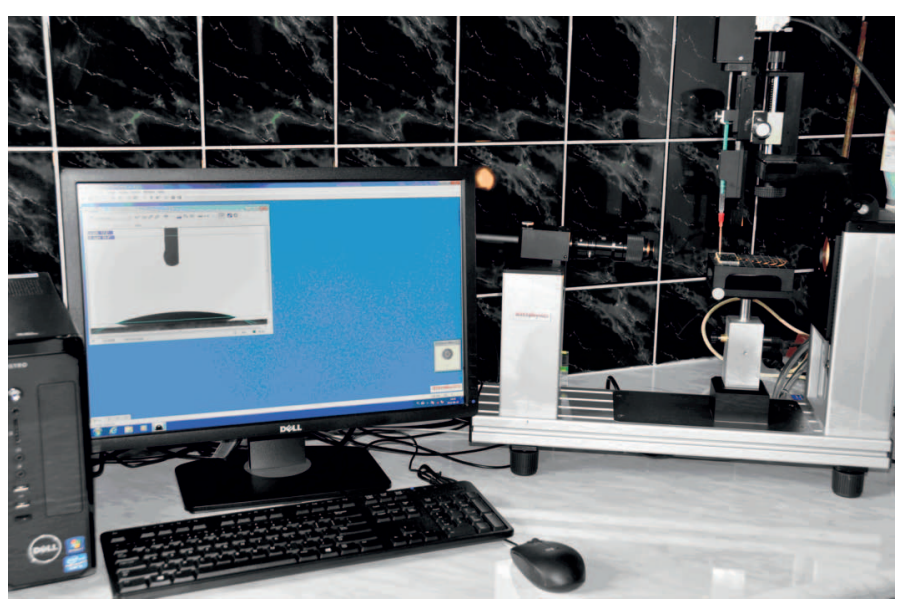

Fot. 1. Aparat do pomiaru kąta zwilżania (goniometr)

Badania zwilżalności, a co za tym idzie - hydrofilowości, prowadzi się z reguły dla powierzchni, na których znajduje się dany materiał. Jednakże w celu określenia hydrofilowości cieczy dokonano inwersji i materiałem badanym nie była powierzchnia, lecz ciecz (zaczyn cementowy).

\section{Omówienie wyników}

Badania parametrów reologicznych kontrolnych zaczynów wiertniczych oraz zaczynów z dodatkiem środków dyspergujących wykonano przy 12 zakresach prędkości obrotowych. Na rysunku 4 zestawione zostały krzywe płynięcia zaczynów kontrolnych oraz zaczynów po wprowadzeniu dodatków superplastyfikatora SPA, natomiast rysunek 5 przedstawia krzywe płynięcia zaczynów kontrolnych i zaczynów po wprowadzeniu dodatków superplastyfikatora SPB. Użycie dodatku superplastyfikatora SPA w ilości $0,25 \%$ (masowo) powoduje obniżenie krzywej naprężeń ścinających w porównaniu z zaczynem kontrolnym o współczynniku w/c $=0,46$. Kolejne zwiększenie ilości dodatku superplastyfikatora skutkuje obniżeniem naprężeń ścinających (rysunek 4). Widoczne na rysunku 5 zestawienie krzywych płynięcia dla zaczynów z dodatkiem superplastyfikatora SPB potwierdza obniżanie wartości naprężeń ścinających wskutek jego zastosowania. Porównując obydwa zestawienia na rysunkach 4 i 5 , można zauważyć skuteczniejsze działanie środka dyspergującego SPB, ponieważ już przy ilości dyspergatora $0,5 \%$ (w stosunku do masy cementu) krzywa naprężeń ścinających znajduje się poniżej krzywej kontrolnej zaczynu o współczynniku w/c = 0,6.

W tablicy 1 zestawiono wyniki parametrów reologicznych zaczynów z dodatkiem środków dyspergujących SPA i SPB oraz wyniki parametrów prób kontrolnych. Omawiane wcześniej obniżenie wartości naprężeń ścinających wskutek

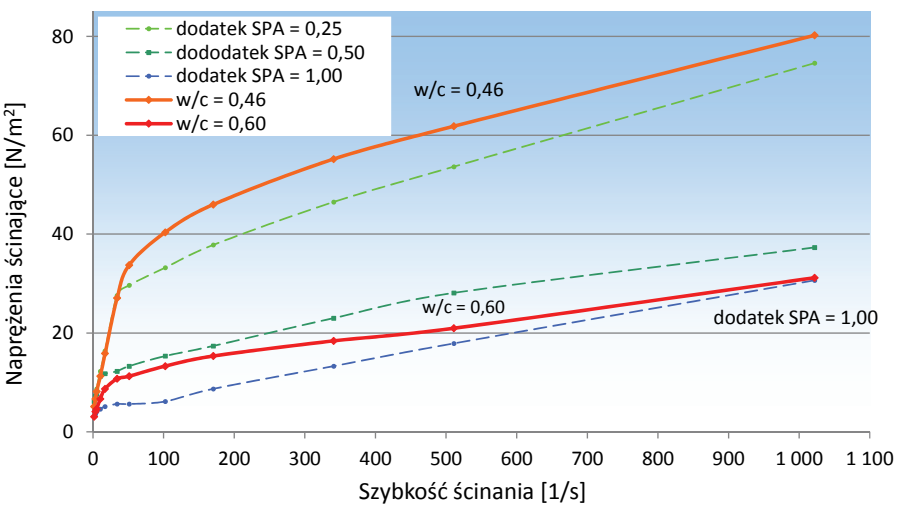

Rys. 4. Porównanie krzywych płynięcia zaczynów z dodatkiem superplastyfikatora SPA oraz zaczynów kontrolnych

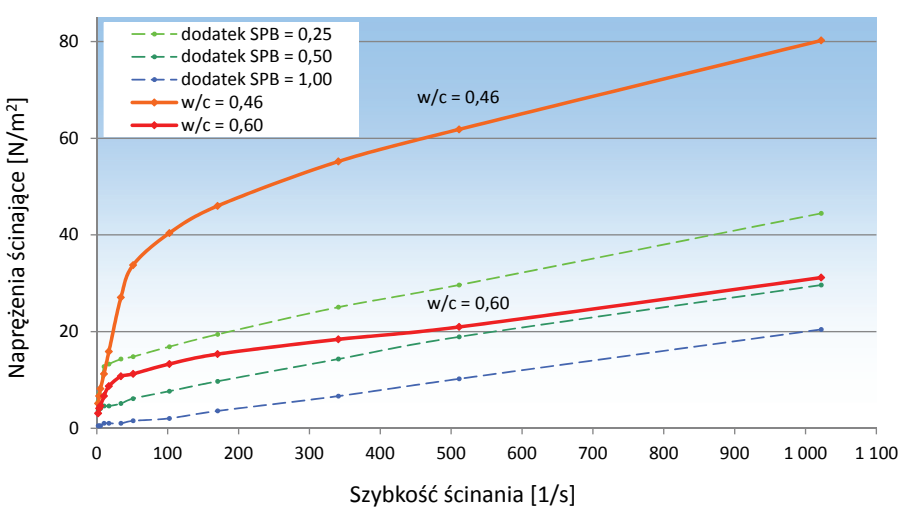

Rys. 5. Porównanie krzywych płynięcia zaczynów z dodatkiem superplastyfikatora SPB oraz zaczynów kontrolnych 
Tablica 1. Porównanie parametrów reologicznych zaczynów z dodatkiem superplastyfikatorów oraz zaczynu bazowego (próba kontrolna $\mathrm{w} / \mathrm{c}=0,46$ )

\begin{tabular}{|c|c|c|c|c|c|c|c|c|}
\hline \multirow{3}{*}{ Parametry reologiczne } & \multirow{2}{*}{\multicolumn{2}{|c|}{$\begin{array}{c}\text { Brak dyspergatora } \\
\text { próba kontrolna }\end{array}$}} & \multicolumn{6}{|c|}{ Dodatek dyspergatora przy stałym $\mathrm{w} / \mathrm{c}=0,46$} \\
\hline & & & \multicolumn{3}{|c|}{ SPA } & \multicolumn{3}{|c|}{ SPB } \\
\hline & $\mathrm{w} / \mathrm{c}=0,46$ & $\mathrm{w} / \mathrm{c}=0,60$ & 0,25 & 0,50 & 1,00 & 0,25 & 0,50 & 1,00 \\
\hline Lepkość Cassona $[\mathrm{Pa} \cdot \mathrm{s}]$ & 0,0468 & 0,0127 & 0,0378 & 0,0124 & 0,0133 & 0,0151 & 0,0132 & 0,0150 \\
\hline Granica płynięcia [Pa] & 9,5401 & 4,8134 & 9,5730 & 7,3656 & 2,6618 & 7,7489 & 2,8899 & 0,1820 \\
\hline Współcz. konsystencji $\left[\mathrm{Pa} \cdot \mathrm{s}^{\mathrm{n}}\right]$ & 21,2376 & 1,9797 & 10,8455 & 0,6820 & 0,0374 & 0,6720 & 0,0985 & 0,0123 \\
\hline
\end{tabular}

zastosowania dodatków dyspergujących znajduje potwierdzenie również w tym zestawieniu. Dodatek superplastyfikatora SPA oraz SPB w ilości 0,5\% powoduje wyraźniejsze obniżenie lepkości plastycznej, granicy płynięcia, a także współczynnika konsystencji zaczynu niż wprowadzenie dodatkowej ilości wody, co ma miejsce w próbie kontrolnej.
Kolejnym etapem prac był pomiar kąta zwilżania, który przeprowadzono na grupie 8 zaczynów (rysunki 6-13). Tak jak w poprzednim cyklu badawczym 2 receptury to zaczyny kontrolne (rysunki 6 i 7) natomiast 6 kolejnych receptur (rysunki 8-13) to składy z dodatkiem superplastyfikatorów. Wyniki pomiarów kąta zwilżania zestawiono w tablicy 2.

Tablica 2. Wyniki badań kąta zwilżania za pomocą goniometru

\begin{tabular}{|c|c|c|c|c|c|c|}
\hline \multirow{2}{*}{ Dodatek } & $\begin{array}{c}\text { Ilość } \\
{[\mathrm{g}]}\end{array}$ & $\begin{array}{c}\text { Kąt lewy } \\
{\left[{ }^{\circ}\right.}\end{array}$ & $\begin{array}{c}\text { Kąt prawy } \\
{\left[{ }^{\circ}\right.}\end{array}$ & $\begin{array}{c}\text { Odchylenie } \\
\text { standardowe }\end{array}$ & Średni wynik & $\begin{array}{c}\text { Uśredniony kąt } \\
\text { zwilżania }\left[\theta^{\circ}\right]\end{array}$ \\
\hline \multirow{3}{*}{ Próba kontrolna } & $\mathrm{w} / \mathrm{c}=0,46$ & 66,5 & 66,5 & 0,00 & 66,5 & $\mathbf{6 6 , 1}$ \\
\cline { 2 - 7 } & $\mathrm{w} / \mathrm{c}=0,60$ & 64,3 & 64,3 & 0,00 & 64,3 & $\mathbf{6 4 , 1}$ \\
\hline \multirow{3}{*}{ SPA } & 0,25 & 62,3 & 61,0 & 0,65 & 61,7 & $\mathbf{6 1 , 3}$ \\
\cline { 2 - 7 } & 0,50 & 39,4 & 36,6 & 1,40 & 38,0 & $\mathbf{3 9 , 2}$ \\
\cline { 2 - 7 } & 1,00 & 29,2 & 26,2 & 1,50 & 27,7 & $\mathbf{2 7 , 7}$ \\
\hline \multirow{3}{*}{ SPB } & 0,25 & 41,6 & 39,2 & 1,20 & 40,4 & $\mathbf{4 3 , 5}$ \\
\cline { 2 - 7 } & 0,50 & 32,9 & 30,2 & 1,35 & 31,6 & $\mathbf{3 1 , 1}$ \\
\cline { 2 - 7 } & 1,00 & 21,7 & 20,9 & 0,40 & 21,3 & $\mathbf{2 1 , 1}$ \\
\hline
\end{tabular}

W przypadku kąta zwilżania liczba prób wynosi 6 , średnie odchylenie standardowe na poziomie $\pm 0,81$.
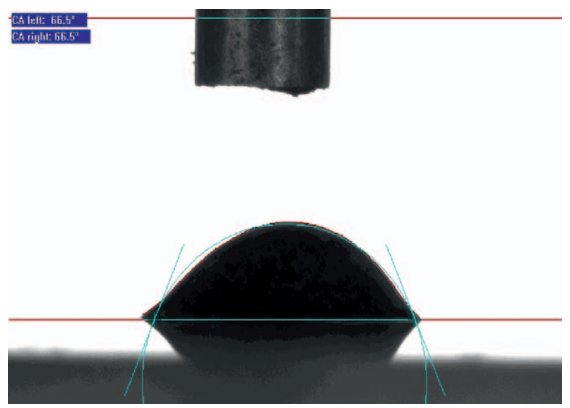

Rys. 6. Próbka kontrolna w/c = 0,46

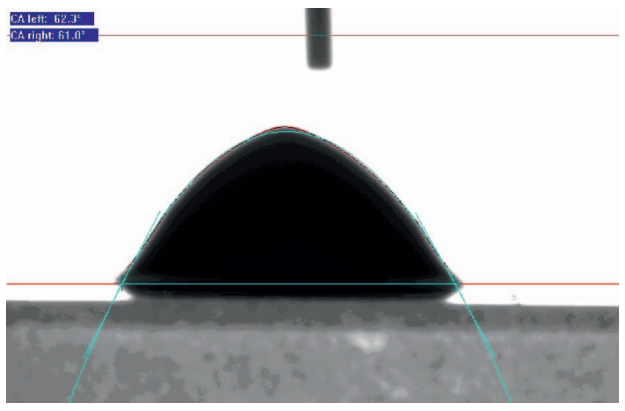

Rys. 8. Próbka z dodatkiem SPA w ilości 0,25\% $(\mathrm{w} / \mathrm{c}=0,46)$
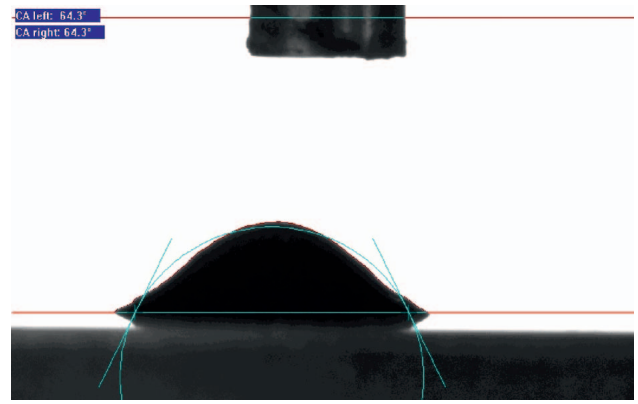

Rys. 7. Próbka kontrolna w/c $=0,60$

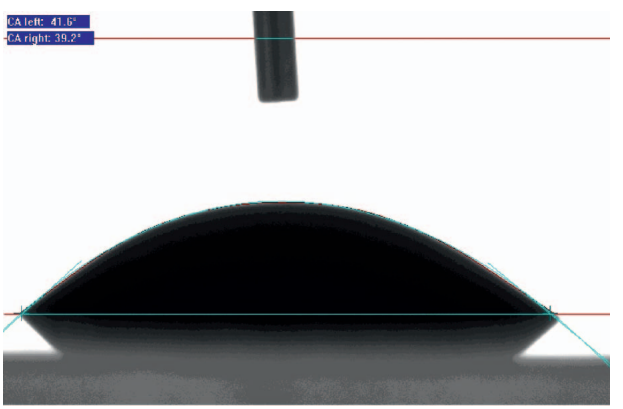

Rys. 9. Próbka z dodatkiem SPB w ilości 0,25\% (w/c = 0,46) 

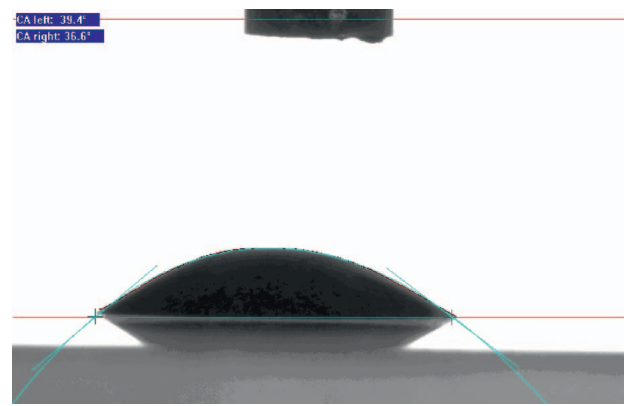

Rys. 10. Próbka z dodatkiem SPA w ilości $0,50 \%(\mathrm{w} / \mathrm{c}=0,46)$
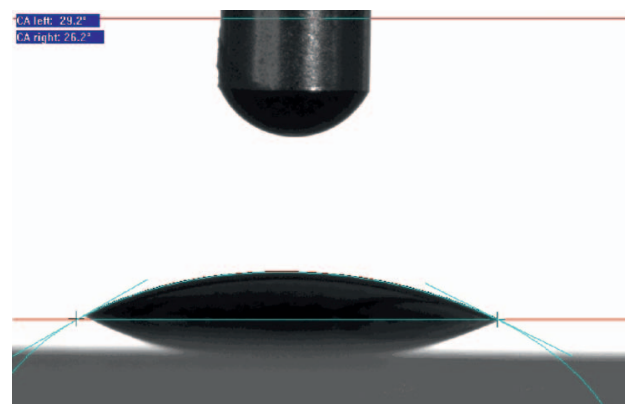

Rys. 12. Próbka z dodatkiem SPA w ilości 1,0\% (w/c = 0,46)

Na rysunku 14 zaznaczono wartości kąta zwilżania, a następnie wykreślono wielomianową linię trendu dla próby kontrolnej oraz zaczynów z dodatkiem superplastyfikatorów.

Analizując uzyskane wyniki badań, zaobserwowano wyraźne obniżanie wartości kąta zwilżania po zastosowaniu dodatku superplastyfikatora (rysunki 8-13). Stwierdzono, że upłynnienie zaczynu cementowego poprzez zwiększenie współczynnika wodno-cementowego nie skutkuje aż tak wyraźnym zmniejszeniem wartości kąta zwilżania (rysunki 6 i 7). Uzyskane wyniki badań pozwalają stwierdzić, że dodatek środka dyspergującego w postaci superplastyfikatora SPA oraz SPB powoduje zmniejszenie kąta zwilżania i tym samym wzrost hydrofilowości zaczynu.
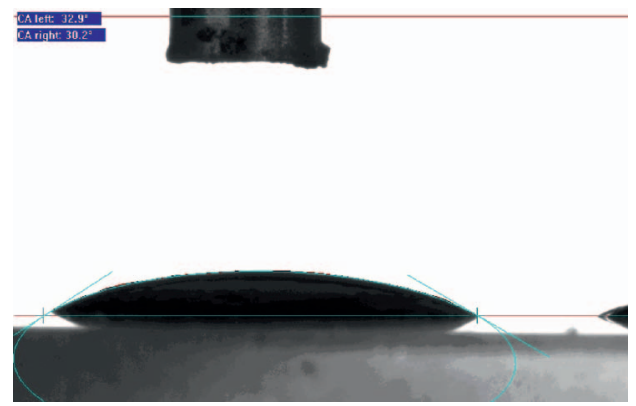

Rys. 11. Próbka z dodatkiem SPB w ilości 0,50\% (w/c = 0,46)
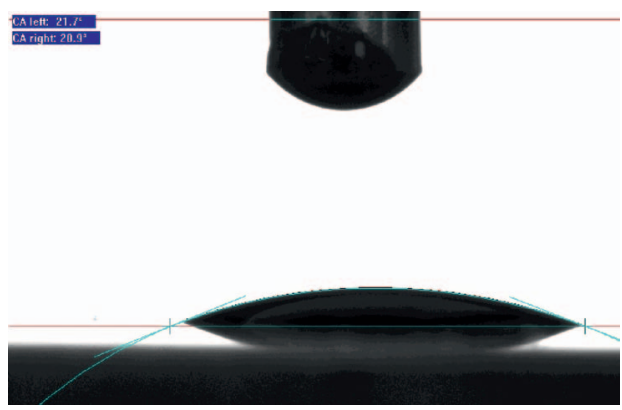

Rys. 13. Próbka z dodatkiem SPB w ilości 1,0\% $(\mathrm{w} / \mathrm{c}=0,46)$

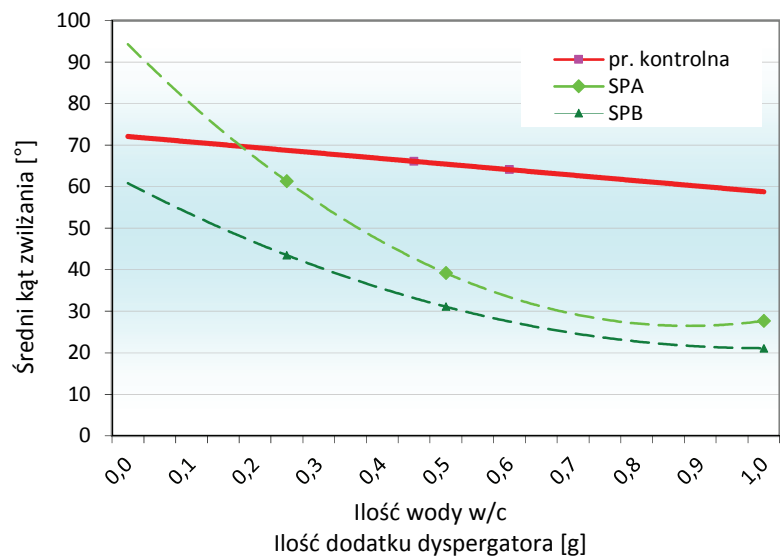

Rys. 14. Porównanie kąta zwilżania w zależności od stosunku wodno-cementowego oraz w zależności od ilości dodatku superplastyfikatorów SPA i SPB

\section{Podsumowanie i wnioski}

Prace badawcze prowadzone w celu oceny wpływu zwilżalności i powiązanej z nią hydrofilowości i hydrofobowości cieczy wykazały, że wprowadzenie do zaczynu superplastyfikatora powoduje obniżenie kąta zwilżania. Znacznie mniejszy wpływ na zmianę wartości kąta zwilżalności zaobserwowano podczas obniżania parametrów reologicznych poprzez zwiększenie ilości wody zarobowej. Stwierdzono, że to właśnie dodatek środka dyspergującego spowodował wzrost hydrofilowości zaczynu cementowego.

Użycie goniometru do badań zaczynów cementowych nie było dotychczas praktykowane, dlatego też uzyskane rezultaty prac są wynikami z badań pilotażowych. Zrealizowane prace badawcze umożliwiają wstępną ocenę „hydrofilowości” zaczynu cementowego na podstawie pomiaru kąta zwilżania. Taka cecha zaczynu cementowego może być przydatna z punktu widzenia dokładniejszego zwilżenia powierzchni styku z formacją skalną oraz stalową powierzchnią rur okładzinowych. Może się to przekładać na poprawę efektywności uszczelniania kolumn rur okładzinowych. Jednakże w celu potwierdzenia owej tezy należy przeprowadzić dodatkowy cykl szczegółowych badań.

Nadmienić należy, że badanie kąta zwilżania zaczynów cementowych jest zasadne tylko w przypadku niskich wartości lepkości plastycznej oraz współczynnika konsystencji zaczynu. Pomiar kąta zwilżania w zaczynach cementowych jest bardzo utrudniony ze względu na wewnętrzne siły strukturalne 
występujące podczas hydratacji zaczynu. W przypadku gdy z zaczynu nie uformuje się regularna kropla o kulistym kształcie, program nie może dopasować elipsy w celu dokładnego pomiaru kątów. Ma to związek z faktem, że kąt zwilżania jest w pewnym sensie determinowany przez napięcie powierzchniowe i siłę ciężkości. W związku z powyższym niekiedy stoż- kowy kształt uzyskanej kropli to wynik superpozycji dwóch sił (napięcia powierzchniowego utrzymującego kroplę w kształcie kulistym oraz siły ciężkości powodującej rozmycie kropli na powierzchni). Z tego względu w celu potwierdzenia właściwości hydrofilowych zaczynów cementowych o wysokich lepkościach można wykonać próby badawcze metodą lameli.

Prosimy cytować jako: Nafta-Gaz 2018, nr 10, s. 745-751, DOI: 10.18668/NG.2018.10.06

Artykuł nadesłano do Redakcji 29.05.2018 r. Zatwierdzono do druku 02.10.2018 r.

Artykuł powstał na podstawie pracy badawczej pt.: Analiza możliwości poprawy efektywności uszczelniania rur okładzinowych poprzez zastosowanie nowych dodatków do zaczynów cementowych - praca Instytutu Nafty i Gazu - Państwowego Instytutu Badawczego na zlecenie Ministerstwa Nauki i Szkolnictwa Wyższego; numer zlecenia: 35/KW/15, numer archiwalny: DK-4100-35/15.

\section{Literatura}

[1] Bogucki Z.A., Płonka B.: Kliniczna ocena masy wyścielającej Flexor. Protet. Stomatol. 1996, t. 34, nr 4, s. 366-368.

[2] Courard L.: Parametric study for the creation of the interface between concrete and repairs products. Materials and Structures 2000, vol. 33, s. 65-72.

[3] Courard L., Garbacz A., Piotrowski T.: Inżynieria powierzchni betonu. Cz. 3. Termodynamiczne uwarunkowania adhezji. Materiały Budowlane 2007, nr 2, s. 6-7.

[4] Czarnecki L., Chmielewska B.: Uwarunkowania adhezji $w$ złaczach budowlanych. Cement-Wapno-Beton 2005, $\mathrm{nr} 2$, s. 74-85.

[5] Czarnecki L., Kurdowski W.: Future developments in concrete. [W:] Mindess S. (ed.): Developments in the Formulation and Reinforcement of Concrete. Woodhead Publishers Ltd., Abington, Cambridge 2008, s. 270-284.

[6] Dębińska E.: Wyznaczanie statycznej wytrzymałości strukturalnej $i$ wczesnej wytrzymałości mechanicznej zaczynów cementowych. Nafta-Gaz 2013, nr 2, s. 134-142.

[7] Ignerowicz A.: Domieszki dyspergujace w technologii produkcji drobnowymiarowych elementów wibroprasowanych. Materiały Budowlane 2013, nr 11, s. 110-111.

[8] Janowska-Renaks E.: Hydrofilowość miara efektywności dziatania superplastyfikatora. Budownictwo i Architektura 2013, vol. 12, nr 3, s. 169-176.

[9] Janowska-Renkas E.: Traditional and new superplasticizers as rheological properties of cement pastes modifiers. [W:] M. Dziubiński, K. Antosik (eds.): Reology - theory and application, EKMA, Warszawa 2011, s. 105-124.

[10] Kurdowski W.: Chemia cementu i betonu. Polski Cement Sp. z o.o., 2010.

[11] Łukowski P.: Rola chemii budowlanej w kształtowaniu wspótczesnego betonu. Materiały Budowlane 2013, nr 11, s. 96-97.
[12] Morażyn T., Lamenta A., Kokowska J.: Test of changes of dynamic contact angle of the concrete hydrophobic impregnation. Building Research Institute - Quarterly 2013, vol. 166, nr 2, s. $3-11$.

[13] Najduchowska M., Pichniarczyk P.: Wpływ związków hydrofobowych na właściwości zapraw cementowych i gipsowych. Cement-Wapno-Beton 2010, nr 3, s. 141-148.

[14] Neville A.M.: Właściwości betonu. Stowarzyszenie Producentów Cementu 2012, s. 1-900.

[15] Rzepka M., Stryczek S.: Laboratoryjne metody określania parametrów technologicznych świeżych zaczynów uszczelniajacych przed zabiegiem zwiąanym z procesem uszczelniania kolumn rur okładzinowych w otworach wiertniczych. Wiertnictwo, Nafta, Gaz 2008, t. 25, z. 2, s. 625-636.

[16] Sobolewski E., Frączak B., Błażewicz S., Seńkol K., Lipski M.: Porównanie kąta zwilżalności podstawowych materiałów protetycznych stosowanych $w$ wykonawstwie protez ruchomych $w$ badaniach in vitro. Protet. Stomatol. 2009, vol. 59, nr 6, s. 401-406.

[17] Stryczek S.: Wplyw superplastyfikatorów na właściwości reologiczne zaczynów cementowych. Nowoczesne Budownictwo Inżynieryjne 2011, nr 3, s. 60-62.

[18] Stryczek S., Wiśniowski R., Kumala B.: Wpływ superplastyfikatora na parametry technologiczne zaczynów uszczelniajacych sporządzonych na osnowie cementów portlandzko-popiołowych. Wiertnictwo, Nafta, Gaz 2008, t. 25, z. 2, s. 717-730.

[19] Wilk K., Kasza P., Czupski M.: Zastosowanie nanocieczy jako dodatków wspomagajacych proces wypierania ropy naftowej. Nafta-Gaz 2014, nr 1, s. 14-20.

[20] Wiśniowski R.: Metodyka określania modelu reologicznego cieczy wiertniczej. Wiertnictwo, Nafta, Gaz 2001, t. 18, z. 1, s. 247-261.

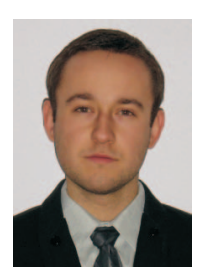

Dr inż. Marcin KREMIENIEWSKI

Adiunkt w Zakładzie Technologii Wiercenia

Instytut Nafty i Gazu - Państwowy Instytut Badawczy

ul. Lubicz $25 \mathrm{~A}$

31-503 Kraków

E-mail: marcin.kremieniewski@inig.pl

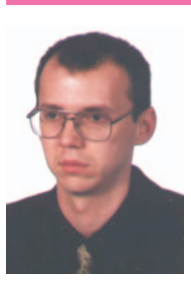

Dr inż. Marcin RZEPKA

Kierownik Laboratorium Zaczynów Uszczelniających w Zakładzie Technologii Wiercenia

Instytut Nafty i Gazu - Państwowy Instytut Badawczy ul. Lubicz 25 A

31-503 Kraków

E-mail: marcin.rzepka@inig.pl 